\title{
Duale plaatjesremming of alleen aspirine voor secundaire cardiovasculaire preventie
}

Ralph Harskamp, Geert-Jan Geersing

Aspirine geldt al decennia als de hoeksteen voor de preventie van hart- en vaatziekten ( $\mathrm{HVZ}$ ) bij patiënten met reeds aangetoonde $\mathrm{HVZ}$ of een hoog risico hierop. Een recente Cochranereview laat zien dat het toevoegen van een tweede plaatjesremmer (clopidogrel) naast aspirine, de kans op een (nieuw) myocardinfarct of ischemisch CVA nog verder verlaagt. Toch is voorzichtigheid geboden, want dit positieve effect moet worden afgezet tegen een verhoogd risico op bloedingen.

Salicylaten (zoals aspirine) remmen de vorming van het prostaglandine tromboxaan A2. Door dit mechanisme remt aspirine de trombocytenaggregatie en daarmee het risico op een myocardinfarct en ischemisch CVA. Clopidogrel heeft eveneens een plaatjesremmend effect via binding aan bloedplaatjesreceptoren voor adenosinedifosfaat (ADP). Gecombineerd gebruik van salicylaten en clopidogrel heeft een versterkend, synergistisch effect op de plaatjesremming (in jargon: duale plaatjesremming) met mogelijk een extra beschermend effect op cardiovasculaire events.

\section{DE COCHRANE-REVIEW}

De auteurs includeerden 15 gerandomiseerde onderzoeken met in totaal 33.970 patiënten die werden behandeld met aspirine en clopidogrel versus alleen aspirine voor een verhoogd cardiovasculair risico of reeds aangetoonde HVZ. ${ }^{1}$ De duur van de behandeling was ten minste 30 dagen en in 2 onderzoeken langer dan 1 jaar (gemiddeld namelijk 28 maanden en 8,2 jaar). Het relatief risico op het ontwikkelen van een myocardinfarct of ischemisch CVA voor aspirine en clopidogrel versus alleen aspirine was respectievelijk 0,78 (95\%-BI 0,69 tot $0,90)$ en 0,73 (95\%-BI 0,59 tot 0,91$)$. Het aantal patiënten dat met duale plaatjesremming moest worden behandeld om bij één extra persoon een myocardinfarct of CVA te voorkomen, was respectievelijk 77 en 43 over een periode van 12 maanden. Er was geen verschil in (cardiovasculaire) mortaliteit.

Het relatief risico op majeure en mineure bloedingen was respectievelijk 1,44 (95\%-BI 1,25 tot 1,64) en 2,03 (95\%-BI 1,75 tot 2,63$)$. Omgerekend geldt dat bij duale plaatjesremming 9 majeure bloedingen en 33 mineure bloedingen extra worden veroorzaakt per 1000 behandelde patiënten (number needed to harm 111 en 30). De auteurs concluderen dat er sprake is van een verlaagd risico op het ontwikkelen van een myocardinfarct of ischemisch CVA bij duale plaatjesremming, met als keerzijde een verhoogd risico op bloedingen. Zij wijzen er verder op dat de data over de risico's mogelijk zijn vertekend (4 onderzoeken met laag risico op bias en over het algemeen matige kwaliteit volgens de GRADE-criteria).
DE NHG-

STANDAARDEN

Het NHG adviseert in zijn richtlijnen aspirine voor te schrijven bij 1) secundaire preventie van myocardinfarct; 2) secundaire preventive na TIA en ischemisch CVA; 3) primaire preventie van cardiovasculaire voorvallen bij patienten met een hoog risico op een eerste cardiovasculaire gebeurtenis. Daarnaast geeft de NHG-Standaard Acuut Coro-

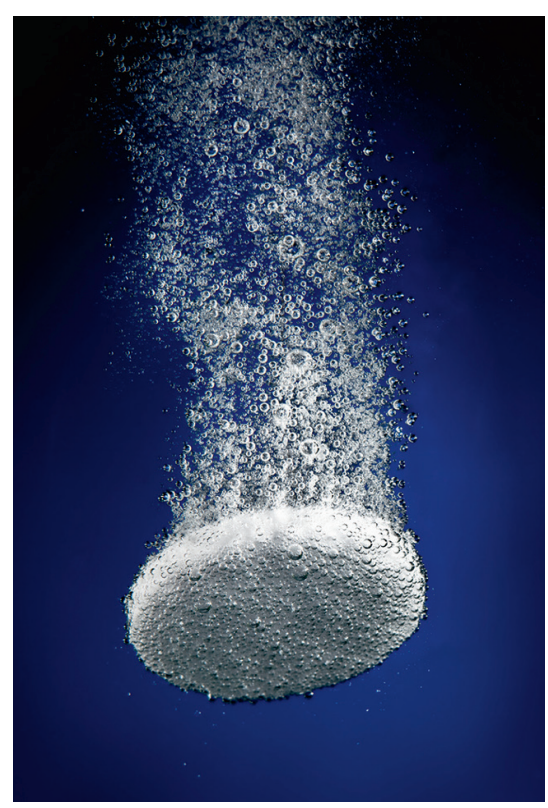

Duale plaatjesremming verlaagt het risico op toekomstige cardiale/cerebrovasculaire events, maar geeft ook een grotere kans op bloedingen.

Foto: iStock nair Syndroom aan dat duale plaatjesremming in de eerste 12 maanden na ACS geïndiceerd is. De richtlijn over TIA of herseninfarct adviseert clopidogrel als monotherapie of aspirine (in combinatie met dipyridamol).

\section{DILEMMA}

Doen we onze patiënten met hart- en vaatziekten tekort door alleen aspirine te geven om hart- en herseninfarcten te voorkomen? Het antwoord is niet eenduidig. Zoals deze Cochrane-review laat zien, verlaagt duale plaatjesremming weliswaar het risico op toekomstige cardiale/cerebrovasculaire events, maar geeft deze ook een grotere kans op bloedingen. Huisarts en patiënt zullen dus een afweging moeten maken welk risico het zwaarste weegt.

\section{LITERATUUR}

1. Squizzato A, Bellesini M, Takeda A, Middeldorp S, Donadini MP. Clopidogrel plus aspirin versus aspirin alone for preventing cardiovascular events. Cochrane Database Syst Rev 2017;12:CD005158.

Harskamp RE, Geersing G-J. Duale plaatjesremming of alleen aspirine voor secundaire cardiovasculaire preventie. Huisarts Wet 2018;61[7]:66. DOI: 10.1007/s12445018-0193-1.

AMC Amsterdam, afdeling Huisartsgeneeskunde: dr. R.E. Harskamp, huisarts-in-opleiding en onderzoeker, r.e.harskamp@amc.uva.nl. UMC Utrecht, Julius Centrum voor Gezondheidswetenschappen en Eerstelijns Geneeskunde: dr. G-J Geersing, huisarts en onderzoeker. Mogelijke belangenverstrengeling: niets aangegeven. 